\title{
The Peculiarities of Socio-Educational Support of the Future Specialist Professional Formation in Higher Education
}

\author{
Evgeniya V. Gutman ${ }^{1}$, Dmitry A. Krylov², Svetlana A. Arefeva ${ }^{2}$, Svetlana N. Fedorova² ${ }^{2}$ Peter A. Apakaev², \\ Tatyana N. Petrova ${ }^{3} \&$ Valentina A. Komelina ${ }^{2}$ \\ ${ }^{1}$ Institute of Pedagogic and Psychology of Professional Education of Russian Academy of Education, Kazan, \\ Russia \\ ${ }^{2}$ Mari State University, Yoshkar-Ola, Russia \\ ${ }^{3}$ Chuvash State Pedagogical University named after I. Y. Yakovlev, Cheboksary, Russia \\ Correspondence: Evgeniya Vladimirovna Gutman, Institute of Pedagogic and Psychology of Professional \\ Education of Russian Academy of Education, Isaeva Street, 12, Kazan, 420039, Russia. E-mail: \\ alfkazan@mail.ru
}

Received: January 17, 2015

Accepted: January 29, 2015 Online Published: February 26, 2015

doi:10.5539/res.v7n3p286

URL: http://dx.doi.org/10.5539/res.v7n3p286

\begin{abstract}
Socio-educational support in the process of education modernization should exhibit humanitarian nature, flexibility, non-violent and "non-intrusive" character of the educational process that can directly relate to the needs and interests of its members. The heightening attention to every member of the educational process marks the idea of socio-educational support of the specialist's professional development top-priority. In this regard we have identified and described the content of the socio-educational support of a future specialist professional development in higher school that involves creating favorable conditions for personal development, social self-determination and professional establishment of the subjects of education in particular organizational and pedagogical forms, as well as successful possessing necessary competencies in the process of teachers' and students' interaction. The submissions of the article can be valuable for the higher-education teaching personnel and advisors in the educational institutions of both higher and secondary professional education.
\end{abstract}

Keywords: socio-educational support, professional formation, higher education, the conditions of socio-educational support

\section{Introduction}

\subsection{Thematic Justification}

The society demands educated people who can responsibly decide between the alternatives, show mobility, dynamism, constructiveness and ability to cooperate. The professional development of a specialist who will be in-demand in the employment market largely depends on his successful socialization, professional adaptation and readiness to perform professional activities (Gutman, 2011; Ivanov et al., 2015; Levina et al., 2015).

In order to educate a new generation of competitive specialists it becomes necessary to provide socio-educational support, use efficient forms and methods of teaching process and extracurricular activities that can reveal the students' potential and develop their readiness to acquire rapidly changing technologies (Shaidullina et al., 2015). The dynamic development of modern society places a person in the circumstances where it is necessary not only to adapt to society but also make decisions eliciting his personal potential in the surrounding reality, so one of the main objectives and the important outcome of education should become not only the scope of the knowledge acquired but also motivation development, volitional qualities, formation of the value system (Demochkin, 2011; Levina et al., 2015).

The education science and practice is searching for the ways to create and optimize a guaranteed system of students' protection and support. The attention is drawn to the analysis and study of the foreign experience in organizing the socio-educational support in educational institutions as a part of the specific professional work aimed at solving various social problems of the student and the teacher as well as the entire staff of the educational institution. 
The focus on the problem of the socio-educational support of the specialists professional development in higher education is conditioned by the necessity to improve the professional development efficiency and intensifying its social functions. The socio-educational support in the context of education modernization should embody humanitarian character, flexibility, non-violent and "non-intrusive" nature of the educational process that is able to correspond to the needs and interests of its members (Gutman, 2013; Sakhieva et al., 2015; Sibgatova et al., 2015). The heightening attention to the personality of each member of the educational process makes the idea of socio-educational support of the specialists' vocational development prioritized.

\subsection{The Essence of the Socio-Educational Support within a University}

The support assumes maintaining the naturally occurring reactions, processes and conditions of a person; it is aimed at discovering the person's characteristics and fulfilling his potential, encouraging important features of the personality and correcting the development deficiency; it also entitles the legal subject to make his own choice and take responsibility for. A successfully arranged social and educational support opens a prospect of personal growth, facilitates a solution to the problem of development, education, socialization, forms a proactive stance. The performed analysis allows us to regard the process of socio-educational support a complex technology designed to create optimal conditions for personal development, social self-identification and professional development of the members of education in certain organizational-educational forms; it is also directed at mastering the competences that are necessary in teachers and students interaction. The conditions are rendered optimal when they mobilize and perform the individual's potential and result in regular reasonable social functioning, satisfy the wants and exercise rights, compensate for any disadvantages.

\section{Literature Review}

The socio-educational support is defined as a resource for the development of professional education that allows all of the educational process members respond to the changing environmental conditions.

The support in pedagogy is defined as an activity providing the conditions for the subject of the development to make the right choice. The idea of socio-educational support is a complex approach to solving the problems of professional development.

At present the socio-educational science includes a large number of studies on the theory and practice of socio-educational activities, their role in meeting special social, cultural and educational needs of young people. The scientific literature has accumulated a theoretical foundation to set the goals and solve the problems of socio-educational support of professional development of a specialist.

The socio-professional development of a personality is revealed in the works of Basov (2000), Batyshev and Dulov (1998), Zeer (2003), Kaminskaya (2009), Klimov (2004), Kuzmina (1989), Markova (1995), Mitina (2004), Mukhametzyanova (2005) and others.

The researchers are particularly interested in the process of formation and development of professional competence (Goncharik, 2003; Sinenko, 1999; Druzhilov, 2005; Rudneva, 1996; Slobodchikov, 2003; Slastenin, 2004), sensitizing the specialist to continuous professional and personal development, self-studying for creative and productive professional activity.

The nature, the content and the concept of socio-professional development of the future professionals in the national education system are discussed in the works of Bocharova (2010), Zeer (2003), Mukhametzyanova (2005), Klimov (2004), Rogov (2008), Tyushev (2006) and others.

The analysis of pedagogic and psychological research shows the remarkably increased attention of the scientists to the problems of personal, social and professional development of the specialists during university years and in this connection to the issues of professional development and personal self-determination, identifying the benefits for society and self-fulfillment in professional activity.

The formation in scientific literature is described inseparably with development integrating and even substituting these terms for each other especially when it comes to the personality formation and development.

The modern authors (Zeer, 2003; Miklyaeva, Rumyantsev, Tupitsyna, \& Tuzhikova, 2003; Pryazhnikov, 2008; Rogov, 2008; Slyusarev, 1992; Chistyakova, 2003) consider the professional development of a person in all its aspects pointing out its extremely complex and multifaceted phenomenon, a continuous purposeful process of progressive personal changes which provides for the inclusion of a person into a new social environment with its standards of communication, behavior, values. Professional formation involves the development of professional motivation, competence, professionally important qualities. The notion of "professional formation" reflects the degree of the person's mastery of the professional activity psychological structure that corresponds to the 
existing social standards and intrinsic requirements.

The professional formation of a person is regarded as the development of professional competence through the member's training towards conscious acquisition of skills and abilities, tools and models of solving professional tasks; we stick to this opinion considering that the development of professionally important personal qualities is one of the conditions for professional development.

We regard the professional development of a specialist and his socio-educational support from the point of competency-building and person-centered approaches which are the ways of developing and improving human resource.

\section{Results and Discussions}

The development of higher education nowadays depends on the following factors: the education humanization ; the formation of a society basing on knowledge; info-communication progress; the process of globalization and integration. Thereupon we can observe the significant changes in the role, objectives and the conditions of higher education functioning as a social institution. The educational practice should take into account the age-related psychological patterns of human development.

The age of the university students accounts for the period of introduction to the significant activities of value on the one hand, and clash of the ideal and the reality on the other, which can be overcome by personal fulfillment. Socio-educational support that exists in higher education is designed to create opportunities for the students for productive personal development.

\subsection{The Conditions of the Efficient Socio-Educational Support in Higher School}

A necessary condition for socio-educational support becomes the adaptive systems in universities (centers, offices, services, clubs), that can integrate the functions of the subjects' support of the professional and personal development of the students through specific psycho-pedagogical and social approaches that provide individualization and person-centered approach.

In order to increase the efficiency of the process of professional development we have implemented the following activities: methodological classes based on the developed manual "Socio-educational support in higher school as a comprehensive educational technology", the elective course "Designing a career by yourself", the training for confident behavior in the employment market, motivational workshops, individual consulting, supervision system and supervision over the undergraduates. We have implemented a complex of organizational and pedagogical forms: individual counseling, professional newspapers contest, participation in the Students Council for extracurricular activities, activities in the students' associations, social events and volunteer activities, participation in the scientific society of post-graduates. We also have founded the Volunteers' Center the main objective of which is to coordinate the public and social projects and campaigns for agencies and organizations.

The process of socio-educational support is implemented in all kinds of socially significant and useful activities. We pay much attention to stimulate students' participation: CAS activities, clubs, creative associations, studios, intellectual, plot-role-playing, business games and events. The fundamental of the socio-educational support is the promotion of the student from the object of educational activities to the subject of educational socially-significant activity, which supposes the students' independent activity and experience during extracurricular time. This process in higher education is realized through extracurricular activities, students associations (the Volunteers Center, the scientific society of post-graduates), holding social events that encourage students to participate in socially significant activities; taking part in social projects (festivals, volunteer work) under the guidance of the Youth Committee; all implemented projects have been covered in the university press center.

\subsection{The Course of the Experiment}

The survey conducted in terms of the research has shown that leisure and sport have become the most attractive alternative destinations for the students among other kinds of volunteering. Among the incentives and motivations to volunteer the practical skills come first as well as moral satisfaction. However, many students are ready to participate in volunteer activities as a form of career guidance and professional development to determine own capabilities, interests, strengths and weaknesses.

In this regard, one of the objectives of socio-educational support is to enable students themselves to become active leaders and organizers of the activities. Therefore our aim was to stimulate developing open collective forms of management, team forms and traditions in preparation and implementation of voluntary initiatives. In practice the volunteers had the opportunity to participate in all administrative processes: assessing the situation 
and identifying the problems; evaluation of the resources; setting the goals and tasks; planning; personnel matters; decision making; work organization; performing the goals and tasks; monitoring and evaluation; summarizing; analyzing.

An individual educational trajectory of professional development selected by a student allowed to realize a personal version of professional development and satisfy the interests. To design the individual educational trajectories it is necessary to provide a number of conditions: to supply a variety of activities at the university that offer an opportunity to choose a variant of promotion; to keep a certain level of teachers training and interaction between them basing on the unity of purposes and values.

The efficiency of the socio-educational support process of the specialist's professional development can be estimated within a number of criteria.

\subsection{The Criteria and Indicators of the Development of the Professionally Significant Personal Qualities}

We have identified the motivational-axiological criteria as the leading one as it reflects the level of motivation and the level of professionally significant personal qualities development as well as the interest in professional self-development. Its indicators are intrinsic motivation aimed at particular specialty, understanding the essence and significance of the professional personal activity.

The pragmatic criterion is expressed in the level of readiness, i.e. of competence and professionally-significant personal qualities formation, stereotypes and algorithms for social and professional behavior of the individual to practically implement his professional duties, commitments, standards of conduct. Its indicators are organization, determination, perseverance, creativity, ability to develop personally, ability to adapt and work successfully in a variety of situations with different people and groups, take into account different points of view; possess a high level of professional corporativity, rapport, communication skills, tolerance, mutual help in studies and work, readiness to cooperate, interact with members of the personnel, adapt his own opinion to the requirements of a new situation.

The individual-semantic criterion of professional development is characterized by varying degrees of awareness and understanding the professional duties by the personality. Its indicators are the high level of cognitive and professional aptitudes, interests, attitudes, needs and aspirations; understanding and evaluation of the objectives and tasks of professional activity.

The reflexive-evaluative criterion indicates the students' positive, negative or neutral evaluation of their future career and attitude to it, willingness and ability to analyze their professional experience and adopt the experience of others, readiness to self-control, self-regulation and professional self-esteem. The indicators of this criterion include the ability to assess the processes of reality and own social status; introspection of the educational and social activities as well as personal professional activities.

It should be noted that the professional development of the specialist's individuality being an integral characteristic should be compared to the data obtained from a set of different techniques.

\subsection{The Research Methodology}

The diagnostic methods we have selected: the study of motivation in higher education (the methodology proposed by Ilyina, 2005) and the motives of students' educational activity (the methodology proposed by Rean \& Yakunin, 2005) and the methodology of studying the learner's professional motivation and the motivation of organizational behavior based on the Herzberg's theory; the developed technique to self-assess the level of the professionally-significant personal qualities of a humanist to effectively carry out professional activities. We also used a method for determining the professionally-significant personal qualities by Mitina (2004).

The results received in terms of the techniques "Motivation for training in higher school," by Ilina (2005), "The motives for the students' educational activity" by Rean and Yakunin (2005), "Professional motivation" showed differences in students motivation in favor of intrinsic motivation in the experimental group and the external positive motivation in the control group.

\subsection{The Experiment Results}

Studying the students' motivation for education and professional development has brought to the following results: in the experimental group the number of highly motivated students aimed at successful professional development with a high level of readiness for professional work topped more than $9 \%$ compared to the control group results. The changes in the control groups where the students were not involved into socially significant activities offered by the university have also been observed. However, the number of the students showing high motivation cannot be considered significant. The comparative analysis has shown that in the experimental group 
of 50 people $30 \%$ showed a high level of motivation, $59 \%$ - medium and $11 \%$ - low level of motivation. In the control group of 78 people a high level of motivation has been observed among $21 \%$ of the students, $44 \%$ of the students showed average result and 35\%-low one. Thus, the difference in quantitative terms within the high level of motivation makes $9 \%$, and within the average one- $-15 \%$.

The research methodology to estimate the level of professionally-significant personal qualities formation allowed us to record the actively-positive attitude towards a chosen profession and awareness of professionally-significant personal qualities necessary for their development. The concluding assessments in the experimental group have recorded the full formation of professional and socially-significant personal qualities and adequate self-esteem.

\section{Conclusions}

Having summarized the results of the theoretical and experimental work we can conclude that the socio-educational support of professional development of a future specialist in higher school is a complex technology directed to create favorable conditions for personal development, social self-determination and professional development of the education subjects in certain organizational and pedagogical forms, as well as to master the necessary competencies in situations of teachers and students interaction.

The effectiveness of the implementation of socio-educational support of the future specialists professional development in higher school is associated with the development of adaptive systems (centers, services, clubs) containing various forms of socio-educational support integrating its functions through specific psycho-pedagogical and social technologies.

\section{References}

Basov, V. M. (2000). Social and pedagogical aspects of education: Proceedings of the graduate students. Kostroma.

Batyshev, A., \& Dulov, A. V. (1998). Education and personality development of students of educational institutions of the Russian Interior Ministry. Moscow.

Bocharova, V. G. (2010). Socio-pedagogical paradigm of education reform. Teacher education in Russia, 1, 69-74.

Chistyakova, S. N. (2003). Professional self-determination. Bulletin of higher education, 4, 17-19.

Demochkin, S. V. (2011). Socio-pedagogical support of professional development of cadets of military high school (p. 192). (PhD Thesis). Yaroslavl.

Druzhilov, S. A. (2005). Professional competence and professionalism of the teacher. Moscow.

Gluhanyuk, N. S. (2000). Psychology teacher professionalization. Yekaterinburg.

Goncharik, N. G. (2003). Interpersonal competence as the basis for the emergence of modern professionalism. School and Life, 6.

Gutman, E. V. (2011). The nature and content of socio-pedagogical support of professional development of students in the context of globalization and integration. Education and self education, 3(25), 157-163.

Gutman, E. V. (2013). Socio-pedagogical support of university students as a factor in their personal and professional formation. Kazan Pedagogical Journal, 1, 108-114.

Ilyina, T. I. (2005). Motivation training in high school. Retrieved from http://testoteka.narod.ru/ms/1/05.html

Ivanov, V. G., Shaidullina, A. R., Drovnikov, A. S., Yakovlev, S. A., \& Masalimova, A. R. (2015). Regional Experience of Students' Innovative and Entrepreneurial Competence Forming. Asian Social Science, 11(1), $35-40$.

Kaminskaya, M. V. (2009). Professional development of teachers in the process of development of their activities within the developmental education. Retrieved May 7, 2009, from http//www.inter-pedagogika.ru

Klimov, E.A. (2004). Psychology of professional self-determination. Saint Petersburg.

Kuzmina, N. V. (1989). The professionalism of the teacher and trainer training vocational schools. Moscow.

Levina, E. Y., Akhmetov, L. G., Latipova, L. N., Mirzagitova, A. L., Mirzanagimova, F. I., Latipov, Z. A., \& Masalimova, A. R. (2015). Diagnostics of Educational Activity Quality on the Basis of Qualitative Methods. Asian Social Science, 11(4), 246-251.

Markova, A. K. (1995). Psychological criteria and level of professionalism of teachers (p. 6). Pedagogy. 
Miklyaeva, A. V., Rumyantsev, P. V., Tupitsyna, I. A., \& Tuzhikova, E. S. (2003). Psychological support of professional activity novice psychologists: Teaching manual (p. 71). Saint Petersburg.

Mitina, L. M. (2004). Psychology of work and professional development of teachers (p. 320). Moscow.

Mukhametzyanova, G. V. (2005). Professional education: Issues of quality and scientific and methodological support (p. 319). Kazan.

Pryazhnikov, N. S. (2008). Professional self-determination theory and practice (p. 345). Moscow.

Rean, A. A., Yakunin, V. A., Bordovskaya, N. V., \& Rozum, S. I. (2005). Psychology and pedagogy (p. 432). Saint Petersburg.

Rogov, E. I. (2003). Choice of Profession: Becoming a professional (p. 178). Moscow.

Rogov, V. I. (2008). Choice of profession: Becoming a professional (p. 333). Moscow.

Rudneva, T. I. (1996). Formation of bases of pedagogical professionalism of university students. Samara.

Sakhieva, R. G., Khairullina, E. R., Khisamiyeva, L. G., Valeyeva, N. S., Masalimova, A. R., \& Zakirova, V. G. (2015). The Syllabus of the Regional Component of Professionally Motivational Education Developed for the Students Specializing in Tourism. Asian Social Science, 11(2), 246-251.

Shaidullina, A. R., Krylov, D. A., Sadovaya, V. V., Yunusova, G. R., Glebov, S. O., Masalimova, A. R., \& Korshunova, I. V. (2015). Model of Vocational School, High School and Manufacture Integration in the Regional System of Professional Education. Review of European Studies, 7(1), 63-67.

Sibgatova, K. I., Mirzagalyamova, Z. N., Pupysheva, E. L., Mirzanagimova, F. I., Shkinderova, I. N., Nuriyeva, E. N., ... Schepkina, N. K. (2015). The Educational Institution Teachers and Professional Community Representatives' Readiness Formation for the Joint Pupils' Career Guidance Implementation. Review of European Studies, 7(1), 74-79.

Sinenko, V. J. (1999). Pedagogy teacher professionalism (p. 5). Pedagogy.

Slastenin, V. A. (2004). Professionalism of the teacher as a pedagogical culture phenomenon. Teacher education and science, 4.

Slobodchikov, V. I. (2003). Professional development of teachers as a scientific problem. Innovation in Education, 5.

Slyusarev, Y. (1992). Psychological support as a factor activating self-identity (PhD Thesis). Saint Petersburg.

Tyushev, Y. (2006). The choice of profession: Training for teenagers. Saint Petersburg.

Zeer, E. F. (2003). Psychology of professions: A textbook for university students (p. 336). Moscow.

\section{Copyrights}

Copyright for this article is retained by the author(s), with first publication rights granted to the journal. This is an open-access article distributed under the terms and conditions of the Creative Commons Attribution license (http://creativecommons.org/licenses/by/3.0/). 